\title{
A MICROTUBE CULTURE METHOD FOR MOUSE OOCYTES
}

\author{
WAN KYOO GHO* \\ University of Cambridge, Cambridge CB2 $3 E G$
}

(Received 23rd October 1973)

The technique developed by Brinster (1963) for the culture of mouse embryos in a drop of medium in paraffin oil in a culture dish has been widely adopted for in-vitro studies of the oocytes and early embryos of various mammals. Development of other culture systems which are able to avoid contact of the medium with paraffin oil by interposing an air compartment between the medium and the oil (Friedhandler, 1961; Mulnard, 1965), or which keep the medium exposed to air (Whitten, 1971; Gwatkin \& Haidri, 1973), have been attempted by several workers.

The basis of the culture system described in this paper is a $50-\mathrm{mm}$ glass tube (i.d. $1 \mathrm{~mm}$ ) obtained from the end of a disposable 9in-long Pasteur pipette (Harshaw Chemicals). The tubes were washed, and sterilized in a hot air sterilizer before use. The culture system was set up by inserting $10 \mu \mathrm{l}$ of a modification of Krebs-Ringer bicarbonate solution (Biggers, Whitten \& Whittingham, 1971) into the middle of each tube with a capillary pipette so that it occupied about $8 \mathrm{~mm}$ of the tube length. Before introducing eggs or embryos into the medium, the tube was plugged at one end with paraffin oil $(5 \mu \mathrm{l})$ and incubated with $5 \% \mathrm{CO}_{2}$ in moistened air at $37^{\circ} \mathrm{C}$ for 2 to $3 \mathrm{hr}$ to obtain equilibration of the medium. After equilibration, ten to fifteen eggs or embryos were introduced under a dissecting microscope into the medium through the open end of the tube with a capillary pipette, and immediately this end was sealed with $5 \mu \mathrm{l}$ paraffin oil, and then the tube containing an air compartment on both sides of the medium was returned to the incubator. The tube system is shown in Text-fig. 1 (a) and the tube holder in Text-fig. 1(b). At any time during the culture period, eggs or embryos could be briefly examined through the wall of the tube with the dissecting microscope.

At the end of the culture period, the tube was cut with a glass knife at the mid-point of each of the two sections containing air, so that the middle piece of the tube containing medium with eggs or embryos was freed from the oil plugs. This piece of the tube was inserted into a micropipette adaptor with rubber bulb (Drummond Scientific Co.) and after the contents had been carefully ejected into a drop of medium in a culture dish, the eggs or embryos were examined under a dissecting microscope. Some of them were fixed with acetic alcohol and stained with $0.5 \%$ aceto-lacmoid for further observation.

Oocyte maturation (Table 1) and cleavage of one-cell (Table 2) or two-cell

* Present address: Department of Zoology, Gollege of Liberal Arts and Sciences, Seoul National University, Seoul, Korea. 


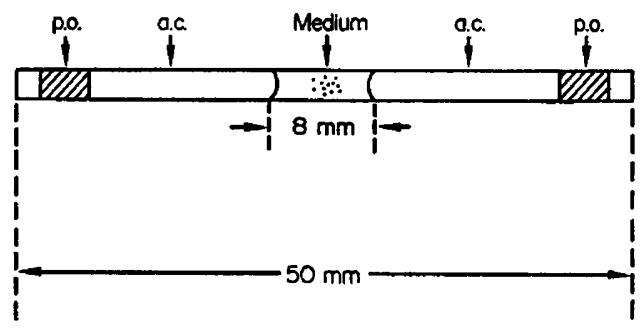

(a)

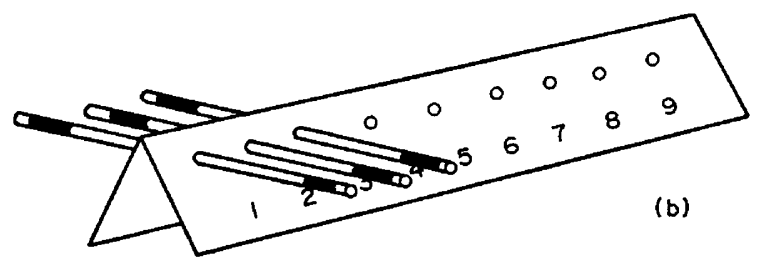

Text-Fig. 1. Microtube culture system. (a) Overall scheme of a microtube. p.o., Paraffin oil; a.c., air compartment. The internal diameter of the tube is about $1 \mathrm{~mm}$. (b) The tube holder may be prepared from a reference card or thick paper.

Table 1. A comparison of the maturation of mouse oocytes in microtube and paraffin-oil culture systems over a period of $20 \mathrm{hr}$

\begin{tabular}{|c|c|c|c|c|c|c|c|}
\hline \multirow{2}{*}{$\begin{array}{l}\text { Culture } \\
\text { system }\end{array}$} & \multirow{2}{*}{$\begin{array}{c}\text { Duration of } \\
\text { culture } \\
(h r)\end{array}$} & \multicolumn{6}{|c|}{ Nuclear phases* } \\
\hline & & $D-P$ & $M I-T I$ & $M I I$ & Act. & Deg. & Total \\
\hline \multirow[t]{4}{*}{ Microtube } & 2 & $\begin{array}{c}28 \\
(93 \cdot 3)\end{array}$ & & - & - & $\stackrel{2}{2}$ & 30 \\
\hline & 8 & $\begin{array}{c}8 \\
(22 \cdot 2)\end{array}$ & $\begin{array}{c}26 \\
(72 \cdot 2)\end{array}$ & 一 & - & $\begin{array}{c}2 \\
(5 \cdot 6)\end{array}$ & 36 \\
\hline & 13 & $\begin{array}{c}3 \\
(9 \cdot 4)\end{array}$ & $\begin{array}{c}9 \\
(28 \cdot 1)\end{array}$ & $\begin{array}{c}19 \\
(59 \cdot 4)\end{array}$ & $\begin{array}{c}1 \\
(3 \cdot 1)\end{array}$ & - & 32 \\
\hline & 20 & $\begin{array}{c}\mathbf{4} \\
(11 \cdot 1) \\
\end{array}$ & $\begin{array}{c}5 \\
(13 \cdot 9) \\
\end{array}$ & $\begin{array}{r}27 \\
(75 \cdot 0) \\
\end{array}$ & - & - & 36 \\
\hline \multirow{4}{*}{$\begin{array}{l}\text { Paraffin oil } \\
\text { in a culture } \\
\text { dish }\end{array}$} & 2 & $\begin{array}{c}36 \\
(100 \cdot 0)\end{array}$ & - & - & - & - & 36 \\
\hline & 8 & $\begin{array}{c}7 \\
(19 \cdot 4)\end{array}$ & $\begin{array}{c}25 \\
(69 \cdot 4)\end{array}$ & 一 & - & $\begin{array}{c}4 \\
(11 \cdot 1)\end{array}$ & 36 \\
\hline & 13 & $\begin{array}{c}3 \\
(8 \cdot 3)\end{array}$ & $\begin{array}{c}10 \\
(27 \cdot 8)\end{array}$ & $\begin{array}{c}21 \\
(58 \cdot 3)\end{array}$ & $\begin{array}{c}1 \\
(2 \cdot 8)\end{array}$ & $\begin{array}{c}1 \\
(2 \cdot 8)\end{array}$ & 36 \\
\hline & 20 & $\begin{array}{c}3 \\
(8 \cdot 3)\end{array}$ & $\begin{array}{c}5 \\
(13 \cdot 9)\end{array}$ & $\begin{array}{c}27 \\
(75 \cdot 0)\end{array}$ & $\begin{array}{c}1 \\
(2 \cdot 8)\end{array}$ & - & 36 \\
\hline
\end{tabular}

* Figures given are the numbers of eggs in each phase, followed by the percentage of the total in parentheses. D-P: dictyate to prophase I; MI-TI: metaphase I to telophase I; MII: metaphase II; Act.: parthenogenetically cleaved egg; Deg.: degenerative egg. Medium: $\mathrm{NaCl} 86.3 \mathrm{~mm}, \mathrm{KCl} 4.78 \mathrm{~mm}$, $\mathrm{KH}_{2} \mathrm{PO}_{4} 1.19 \mathrm{~mm}, \mathrm{CaCl}_{2} 1.71 \mathrm{mM}, \mathrm{MgSO}_{4} 1.19 \mathrm{mM}$, sodium pyruvate $0.33 \mathrm{~mm}$, sodium lactate $25.00 \mathrm{~mm}$, sodium bicarbonate $25.07 \mathrm{~mm}$, glucose $1 \mathrm{mg} / \mathrm{ml}$, bovine serum albumin $4 \mathrm{mg} / \mathrm{ml}$, penicillin $100 \mathrm{U} / \mathrm{ml}$, streptomycin $50 \mu \mathrm{g} / \mathrm{ml}$. 
mouse embryos (Table 3) in the tube-culture system have been compared with those in the ordinary paraffin-oil method. The results obtained from either the the microtube or paraffin-oil culture system are comparable with those of

Table. 2. A comparison of the first cleavage of one-cell fertilized mouse embryos in microtube and paraffin-oil culture systems over a period of $30 \mathrm{hr}$

\begin{tabular}{c|c|c|c}
\hline $\begin{array}{c}\text { Microtube } \\
\text { no. }\end{array}$ & $\begin{array}{c}\text { No. of two-cell } \\
\text { embryos/no. of fertilized } \\
\text { eggs }\end{array}$ & $\begin{array}{c}\text { Medium drop } \\
\text { number in culture } \\
\text { dish }\end{array}$ & $\begin{array}{c}\text { No. of two cell } \\
\text { embryos/no. of } \\
\text { fertilized eggs }\end{array}$ \\
\hline 1 & $9 / 12$ & 1 & $9 / 12$ \\
2 & $9 / 12$ & 2 & $8 / 12$ \\
3 & $7 / 12$ & 3 & $9 / 12$ \\
4 & $6 / 12$ & 4 & $5 / 12$ \\
5 & $8 / 10$ & 5 & $7 / 10$ \\
6 & $9 / 10$ & 6 & $7 / 10$ \\
7 & $7 / 10$ & 7 & $8 / 10$ \\
8 & $8 / 10$ & 8 & $7 / 10$ \\
Total & $63 / 88$ & Total & $60 / 88$ \\
$\%$ & 71.6 & $\%$ & 68.2 \\
\hline
\end{tabular}

The composition of the medium used was the same as that indicated in Table 1 but with a slight modification in the concentration of $\mathrm{NaCl}$ to $66 \cdot 4 \mathrm{~mm}$.

Table 3. A comparison of the cleavage of two-cell mouse embryos to blastocysts in microtube and paraffin-oil culture systems over a period of $80 \mathrm{hr}$

\begin{tabular}{c|c|c|c}
\hline $\begin{array}{c}\text { Microtube } \\
\text { no. }\end{array}$ & $\begin{array}{c}\text { No. of blastocysts/no. } \\
\text { of two-cell embryos }\end{array}$ & $\begin{array}{c}\text { Medium drop } \\
\text { number in culture } \\
\text { dish }\end{array}$ & $\begin{array}{c}\text { No. of blastocysts/no. } \\
\text { of two-cell embryos }\end{array}$ \\
\hline 1 & $8 / 10$ & 1 & $7 / 10$ \\
$2 *$ & $6 / 10$ & 2 & $8 / 10$ \\
3 & $6 / 8$ & 3 & $5 / 8$ \\
4 & $5 / 8$ & 4 & $5 / 8$ \\
5 & $5 / 8$ & 5 & $6 / 8$ \\
6 & $7 / 8$ & 6 & $7 / 8$ \\
7 & $7 / 8$ & 7 & $5 / 8$ \\
Total & $44 / 60$ & Total & $43 / 60$ \\
$\%$ & 73.3 & $\%$ & 71.7 \\
\hline
\end{tabular}

The composition of the medium was the same as that in Table 1 but with slight modifications in the concentrations of $\mathrm{NaCl}$ to $110.35 \mathrm{~mm}$ and of sodium pyruvate to $0.48 \mathrm{~mm}$.

* Three blastocysts which had developed from the premorula stage during a 22-hr journey from Cambridge to Edinburgh are included. The microtube containing the embryos was carried in a tightly sealed plastic test-tube containing equilibrated air. The test-tube was surrounded with cotton-wool and maintained at body temperature.

Donahue (1968) who studied the time sequence of ovum maturation in culture under oil. The production of two-cell embryos from fertilized eggs, or blastocysts from two-cell embryos, is also comparable between the two systems. 
The tube-culture method has several advantages. Culture with oil-soluble substances is now feasible because the medium is isolated from oil. Changes in $\mathrm{pH}$, humidity and gas tension are minimized with this system. The handling of the tubes containing medium is very simple and safe and there is no risk of spilling the medium or the oil. It is relatively easy to transport embryos for some distance while they are still undergoing development. The system is less expensive than the ordinary culture system because only small amounts of medium and paraffin oil are required, and the culture tube is readily obtainable. Finally, a brief observation of the cells during the culture period is possible whenever required. By developing this system, metabolic studies of the eggs and early embryos could be achieved more readily, and the effects of fatsoluble agents such as steroid hormones or prostaglandins could be examined. Mailing of the embryos in culture is also a possibility if an appropriate device is developed.

The work was supported by a research grant from the Ford Foundation to Professor C. R. Austin. The author was a WHO Fellow from 1971 to 1973.

\section{REFERENGES}

Biggers, J. D., Whitten, W. K. \& Whittingham, D. G. (1971) The culture of mouse embryos in vitro. In Methods in Mammalian Embryology, p. 86. Ed. J. C. Daniel, Jr. W. H. Freeman \& Go., San Francisco.

Brinster, R. L. (1963) A method for in vitro cultivation of mouse ova from two-cell to blastocyst. Expl Cell Res. 32, 205.

Donahue, R. P. (1968) Maturation of the mouse oocyte in vitro. 1. Sequence and timing of nuclear progression. F. exp. Zool. 169, 237.

Friedhandler, L. (1961) Pathways of glucose metabolism in fertilized rabbit ova at various preimplantation stages. Expl Cell Res. 22, 303.

Gwatkin, R. B. L. \& HAidri, A. A. (1973) Requirements for the maturation of hamster oocytes in vitro. Expl Cell Res. 76, 1.

Mulnard, J. G. (1965) Studies of regulation of mouse ova in vitro. In Preimplantation Stages of Pregnancy, p. 123. Eds. G.E.W. Wolstenholme and M. O'Connor. Ciba Foundation Symposium. Churchill, London.

Whitren, W. K. (1971) Nutrient requirements for the culture of preimplantation embryos in vitro. Adv. Biosci. 6, 129. 